\title{
Plant presence reduces root and shoot litter decomposition rates of crops and wild relatives
}

\author{
Janna M. Barel $(\mathbb{D}$ - Thomas W. Kuyper (D) \\ Wietse de Boer (D) - Gerlinde B. De Deyn (1)
}

Received: 23 November 2018/Accepted: 8 February 2019/Published online: 18 March 2019

(C) The Author(s) 2019

\begin{abstract}
Aims Roots contribute greatly to carbon cycling in agriculture. Measuring aboveground litter decomposition could approximate belowground turn-over if drivers of decomposition, f.e. litter traits and plant presence, influence shoot and root decomposition in a comparable manner. We tested coordination of above- and belowground litter traits and decomposition rates for six pairs of crops and closely related wild plants and studied the influence of plant presence on decomposition.
\end{abstract}

Responsible Editor: Cindy Prescott.

Electronic supplementary material The online version of this article (https://doi.org/10.1007/s11104-019-03981-7) contains supplementary material, which is available to authorized users.

J. M. Barel $(\bowtie) \cdot$ T. W. Kuyper • W. de Boer •

G. B. De Deyn

Soil Biology Group, Wageningen University \& Research, PO Box 47, 6700 AA Wageningen, The Netherlands

e-mail: janna.barel@wur.nl

T. W. Kuyper

e-mail: thom.kuyper@wur.nl

W. de Boer

e-mail: w.deboer@nioo.knaw.nl

G. B. De Deyn

e-mail: gerlinde.dedeyn@wur.nl

W. de Boer

Microbial Ecology, Netherlands Institute for Ecology (NIOO-KNAW), PO Box 50, 6700 AB Wageningen, The Netherlands
Methods Above- and belowground traits were measured, compared and related to decomposition rates. Shoot and root litters were incubated in presence of the same plant species as the litter species (own) or in presence of two other plant species (a grass or forb).

Results Shoots decomposed 1.43-1.98 times faster than (resp.) wild plant and crop roots. Decomposition correlated negatively with litter carbon and lignin concentrations, except crop root decomposition which correlated negatively with nitrogen concentration. Unexpectedly, plant presence reduced litter decomposition, with strongest effects for root litters in presence of forbs.

Conclusions Carbon cycling might be slower than predicted solely based on shoots decomposition rates, especially in presence of growing plants. While root decomposition of wild plants can be approximated by shoot decomposition, crop shoots are a poor proxy for crop root decomposition.

Keywords Rhizosphere priming · Litter quality · Plant functional traits - Above- and belowground trait coordination - Domestication - Microbial $\mathrm{r}$ - and $\mathrm{K}$ strategy

\section{Introduction}

In both natural and agro-ecosystems, plant roots are a major source of biomass for carbon-cycling (Freschet et al. 2013; Jackson et al. 2017). In natural grasslands, roots account up to $60 \%$ of primary productivity (Jackson et al. 2017), and represent $33 \%$ of the average 
annual litter input (Freschet et al. 2013). In croplands, roots on average represent $10 \%$ of plant biomass production of which $46 \%$ carbon (C) is retained in soil organic matter versus only $8 \%$ of aboveground $\mathrm{C}$ inputs into soil (Jackson et al. 2017). Comparing root to shoot decomposition is highly relevant because aboveground litter decomposition could be an easily measurable proxy for root decomposition.

Decomposition of plant litter is controlled by litter quality along with abiotic and biotic environmental conditions (Cornwell et al. 2008; Silver and Miya 2001; Swift et al. 1978). Specifically litter nitrogen (N) concentration is generally found to stimulate decomposition, while concentrations of structure-related compounds, measured by $\mathrm{C}$ or lignin concentrations, relate negatively with decomposition rates (Cornwell et al. 2008; Freschet et al. 2012; Vivanco and Austin 2006; Zhang et al. 2008).

Moreover, traits appear to be coordinated across organs of the same plant, e.g. plants with high $\mathrm{N}-$, C- or lignin concentrations in leaves have high values in fine roots too (Freschet et al. 2010). Comparable trait values across plant organs could be the manifestation of similar physiological trade-offs across plant organs, known as the plant-economic spectrum (PES) (Reich 2014). If above- and belowground plant organs display coordinated trait values, it is expected that decomposition rates are likewise correlated.

Pioneering studies demonstrated that interspecific variation in root decomposition is comparable to that in shoot decomposition (Birouste et al. 2012; Freschet et al. 2012; Vivanco and Austin 2006) with roots of grassland species decomposing 1.8 times slower than leaves (Freschet et al. 2013). Whenever root decomposition did not reflect leaf decomposition, neither were root and leaf litter traits coordinated (Hobbie et al. 2010). Although these studies indicate that trait coordination underlies coordinated decomposition rates, studies comparing root-shoot decomposition are often confounded by factors influencing the decomposition process, such as litter condition (comparing senesced leaves vs live roots), and incubation location (comparing surface incubation of leaves to buried incubation of roots) (Freschet et al. 2013). In agriculture above- and belowground plant residues, such as cover crops, are incorporated into the soil (Dias et al. 2014; Thorup-Kristensen et al. 2003; Wagger et al. 1998). This stresses the need to test coordination of traits and decomposability of root and shoot litters under the same conditions.
Domestication of crops has selected for resource acquisitive plant traits (García-Palacios et al. 2013; Roucou et al. 2018), thus crops are expected to have higher litter $\mathrm{N}$ but lower litter $\mathrm{C}$ and lignin concentrations than their wild relatives. For crop leaf litter, chemical traits and decomposability of are in line with PES theory, identifying crops as highly acquisitive plants with highly decomposable shoots (García-Palacios et al. 2013). However, it is unclear whether crop root traits and decomposability display similar responses to human selection. Crop breeding appears to have led to loss of coordination between above- and belowground traits (Milla et al. 2014; Roucou et al. 2018), which could make crop shoot decomposition an unsuitable proxy for crop root decomposition.

A large body of literature suggests that presence of growing plants can influence the breakdown of organic materials (Huo et al. 2017; Kuzyakov 2010), but plantinduced changes to litter decomposition are rarely quantified. Increase of decomposition rates in plant presence is referred to as positive priming, and reduction as negative priming (Bingeman et al. 1953). Positive priming can arise when plant rhizodeposits supply the decomposer community with labile C-compounds, thus providing an energy-source to mine soil organic matter (SOM) for $\mathrm{N}$ (Chen et al. 2014). Mechanisms for negative priming are proposedly dependent on mineral $\mathrm{N}$ availability (Dijkstra et al. 2013). At low $\mathrm{N}$ availability, plants and decomposers might compete for $\mathrm{N}$, thus increasing decomposition, while at high $\mathrm{N}$ availability decomposers could prefer rhizodeposits as a $\mathrm{C}$ source as there is no need to decompose organic matter for N (Dijkstra et al. 2013). Development of this theory is based on studies where priming effects of growing plants or fresh substrate additions are studied on decomposition of old SOM. Whereas many studies looked at rhizosphere priming of (old) soil organic matter (Huo et al. 2017), only few studies focussed on priming of fresh organic matter, i.e. plant litters (for example Cheng and Coleman (1990); Saar et al. (2016); Shi et al. (2018)), despite the relevance of exploring the extent of priming effects of plants on fresh litter decomposition for our understanding of Ccycling, particularly in agro-ecosystems.

Similar to priming effects on SOM, a growing plant could stimulate litter decomposition by providing the decomposers with rhizodeposits as a labile energy-source (Chen et al. 2014). Van der Krift et al. (2001) reported increased decomposition and $\mathrm{N}$ mineralisation rates of grass root litters in presence of growing grasses. In another 
study monitoring of C-loss from labelled root litter confirmed positive priming effects of growing grasses on grass root decomposition rates (van der Krift et al. 2002). Both studies found differences in priming effects between different priming plant species and between primed litter species. Positive priming was also observed for winter rye (Secale cereale), which stimulated $\mathrm{C}$ mineralisation from rye straw (Cheng and Coleman 1990). In contrast, mineralisation of $C$ from labelled straw was decreased in presence of a growing rape plant (Brassica napus), proposedly because of $\mathrm{N}$ competition between plant and decomposers (Bek 1994). Negative priming effects were also found when saprotrophic organisms were not competing for mineral $\mathrm{N}$ with the present plant. Presence of white clover (Trifolium repens) had negative priming effects on non-legume root litters, whereas legume-root litters were not influenced (Saar et al. 2016). Additionally, the magnitude of the priming effect covaried with the quality of the litter, with most negative priming effects for litter with low $\mathrm{N}$ - and $\mathrm{P}$-concentrations (Saar et al. 2016). These studies suggest that direction and the extend of priming effects on decomposing litter could vary with plant species identity and with litter quality. Yet, experiments systematically combining a range of plant species and a litter quality gradient are lacking.

The objective of this study is two-fold. First, we assess how shoot and root litters of crops and wild relatives differ in chemical traits and decomposition rates. Second, we examine the influence of growing plants on root and shoot litter decomposition and test the relationship with litter quality. Litters of six pairs of crops and closely related wild plants were incubated in absence and presence of growing plants to test the following hypotheses: 1) shoot and root litter chemical traits and decomposition rates of crops and wild relatives are coordinated; 2) crop litters decompose faster than litters of their wild relative because crop litters have higher $\mathrm{N}$ concentrations, but lower $\mathrm{C}$ - and lignin concentrations than wild plant litters; 3) presence of a growing plant stimulates decomposition rates, the magnitude of this priming effect differs with species of plant present and litter quality.

\section{Materials and methods}

Litter preparation

To prepare the plant litter, six pairs of closely related crops and wild relatives (Table 1) were grown as individual plants in sandy soil under greenhouse conditions for ten weeks. Briefly, seeds were surface sterilised with $0.4 \%$ $\mathrm{NaOCl}$ and sown in autoclaved sand to germinate (21:19 ${ }^{\circ} \mathrm{C}$ day:night temperature, light regime of 16:8 h L:D). After 2 weeks, seedlings were transplanted into $2 \mathrm{~L}$ pots (18 cm height, $12 \mathrm{~cm}$ diameter) filled with sandy soil collected from a nearby agricultural field ( $51^{\circ} 59^{\prime}$ 41.9"N, 5³9'17.5"E (Barel et al. 2018)). The soil was sieved ( $8 \mathrm{~mm}$ diameter) and one part was sterilised by $\gamma$ radiation (Synergy Health Ede B.V., Ede, The Netherlands) and another part was kept as fresh soil (stored at $4{ }^{\circ} \mathrm{C}$ ) to reinoculate the sterilised soil with native soil microorganisms. The soil in which the plants for litter production were grown was a mix of 1:9 fresh:sterilised soil. This soil treatment was chosen as these plants served as control plants in an experiment in which plant-soil microbial community relations were studied. The soil used for the decomposition experiment was not sterilised (see below).

Plants were grown for ten weeks under greenhouse conditions $\left(21: 16{ }^{\circ} \mathrm{C}\right.$, ventilation cooled when $>30{ }^{\circ} \mathrm{C}$, 16:8 h L:D) and soil moisture level of $60 \%$ maximum water holding capacity maintained by daily watering. To collect the above- and belowground plant litter shoots were cut at surface level, except for Raphanus plants which were cut at height of the cotyledons. Roots were rinsed to remove soil. Plant biomass was dried at $40{ }^{\circ} \mathrm{C}$. The litter thus comprised freshly cut dried material rather than naturally senesced plant material as to standardise the litter collection, and because in many cropping systems the plant material that is returned to soil is not yet senesced. For each litter species four independent pools of litter were composed of two to five individual plants, such that paired shoot and root litters in this experiment originated from the same pool of plants. For shoot litter, flowers and seeds were omitted, as was the thick plant base of Raphanus species. For root litter only fine roots $(<2 \mathrm{~mm})$ were used. Litterbags were made of polyester fabric ( $0.02 \mathrm{~mm}$ mesh size) sown into pockets of $5 \times 5 \mathrm{~cm}$. Each pocket was filled with $1 \mathrm{~g}$ dry litter cut to fragments of $1 \mathrm{~cm}$. For Avena sativa, Arrhenatherum elatius and Raphanus sp. $0.6 \mathrm{~g}$ of shoot and root litter was used, due to limited litter availability. The exact amount of dry litter in each bag was recorded. Litterbags were closed with three staples.

Litter incubation and plant presence

The decomposition experiment was executed under greenhouse conditions $\left(21: 16{ }^{\circ} \mathrm{C}, 16: 8 \mathrm{~h}, \mathrm{~L}: \mathrm{D}\right.$, March 
Table 1 Overview of crops and closely related natural-grassland plant species used in the experiment assigned to one of six (near) congeneric plant pairs

\begin{tabular}{|c|c|c|c|c|}
\hline & Pair & Family & Plant species & Common name \\
\hline \multirow[t]{6}{*}{ Crops } & 1 & Poaceae & Avena sativa var. Dominik ${ }^{1}$ & Oat \\
\hline & 2 & Poaceae & Lolium perenne var. Mathilde ${ }^{1}$ & Perennial ryegrass \\
\hline & 3 & Fabaceae & Trifolium repens var. Alice ${ }^{1}$ & White clover \\
\hline & 4 & Fabaceae & Vicia sativa var. Ebena ${ }^{1}$ & Common vetch \\
\hline & 5 & Brassicaceae & Raphanus sativus var. Terranova ${ }^{2}$ & Fodder radish \\
\hline & 6 & Asteraceae & Cichorium endivia var. Nummer vijf2 ${ }^{3}$ & Endive \\
\hline \multirow[t]{6}{*}{ Wild relatives } & 1 & Poaceae & Arrhenatherum elatius 4 & False Oat-grass \\
\hline & 2 & Poaceae & Festuca rubra ${ }^{4}$ & Red Fescue \\
\hline & 3 & Fabaceae & Trifolium pratense ${ }^{5}$ & (Wild) red clover \\
\hline & 4 & Fabaceae & Vicia cracca $^{4}$ & Tufted vetch \\
\hline & 5 & Brassicaceae & Raphanus raphanistrum ${ }^{5}$ & Wild radish (jointed charlock) \\
\hline & 6 & Asteraceae & Cichorium intybus ${ }^{5}$ & Common chicory \\
\hline
\end{tabular}

Sources of seeds: 1) AgriFirm Plant, Apeldoorn, NL, 2) J. Joordens' Zaadhandel B.V., Kessel, NL, 3) De Bolster, Epe, NL, 4) Emorsgate, Norfolk, UK, 5) Cruydt-Hoeck, Nijeberkoop, NL

- May 2015 in Wageningen, The Netherlands), over the course of ten weeks. Fresh soil was collected at the aforementioned field in March 2015 and sieved $(8 \mathrm{~mm})$. The soil was sandy with $\mathrm{pH} 5.9$ and contained $1.78 \mathrm{~g}$ total $\mathrm{N} \mathrm{kg}^{-1} \mathrm{dw}$ soil and $4.8 \%$ organic matter. After filling the pots $(2 \mathrm{~L}$ pots, $18 \mathrm{~cm}$ height, $12 \mathrm{~cm}$ diameter), the soil was brought to and maintained at $60 \%$ maximum water holding capacity by daily watering according to the required weight. The pots were not fertilized, nor did they receive any pesticides.

The effect of plant presence on litter decomposition was tested by incubating litters in pots with a present plant of the same species (own), or of two focal plants (grass or forb), or in absence of a plant (control). Focal plants for crop litters were A. sativa (grass) and Cichorium endivia (forb). For wild litter species, A. elatius (grass) and Cichorium intybus (forb) were used. Note, A. sativa litters incubating in pots with growing $A$. sativa plants were thus considered as own-plant treatment as well as grass-focal plant. The experimental design thus included twelve noplant, twelve own-plant, ten grass-focal plant and ten forbfocal plant treatments, and was replicated 4 times, resulting in 176 pots placed in the greenhouse in 4 randomised blocks. Before planting, seeds of all plant species were disinfected with $0.4 \% \mathrm{NaOCl}$, rinsed and sown in autoclaved sand. After two weeks, seedlings were transplanted, one individual per pot. Plants were grown for four more weeks until litterbags were inserted.
In each pot two litterbags were incubated, one with shoot and one with root litter. Litterbags were inserted vertically at $8 \mathrm{~cm}$ depth to maximise the potential area of interaction with growing roots, both litterbags were placed at opposite sides between plant and pot wall. Litters were incubated for six weeks. At the end of the experiment, litterbags were collected and gently rinsed to remove adherent soil and roots. Litterbags were frozen at $-20{ }^{\circ} \mathrm{C}$ and subsequently freeze dried (Alpha 1-4 LD Plus, Martin Christ Gefriertrocknungsanlagen $\mathrm{GmbH}$, Osterode am Harz, Germany). Litterbags were opened, ingrown roots removed and remaining litter dry weight determined.

\section{Litter traits measurements}

Litter N, C and lignin concentrations were measured to characterise the chemical quality of the litters. Analysis was done at the level of pools, thus for each litter species four observations were made resulting in $12 \times 4=48$ root and 48 shoot analysis for each litter trait.

Dried litters were ground (MM2000 ball mill, Retsch Benelux VERDER NV, Aartselaar, Belgium). Ground material was analysed on a CHN analyser (LECO Corporation, St Joseph, Michigan, USA), to obtain litter N and $\mathrm{C}$ concentrations. Lignin concentrations were measured according to Poorter and Villar (1997), which is based on a methanol chloroform extraction followed by 
hydrolysis in $3 \mathrm{M} \mathrm{HCl}$, to remove all non-ligneous compounds (Freschet et al. 2010). The remaining residue, consisting of (hemi-)cellulose, proteins lignin and silicates, is dried for $48 \mathrm{~h}$ at $70{ }^{\circ} \mathrm{C}$, weighted and ground for $\mathrm{CN}$ analysis. Lignin concentration is calculated from the residue $\mathrm{C}$ and $\mathrm{N}$ concentrations.

All litter N, C and lignin concentrations were corrected for ash-content. Lignin-concentrations of eight root samples (one Vicia sativa, three $R$. sativus, one $A$. sativa, three Lolium perenne samples) were found to be negative and were excluded from further data-analysis.

\section{Decomposition rate and priming calculations}

Litter decomposability and priming effects were based on litter decomposition rates. Decomposition rate $k\left(\mathrm{day}^{-1}\right)$ was calculated from fraction remaining mass $\left(f_{\text {rem }}\right)$ as a function of incubation duration ( $t$ (days)) (Olson 1963):

$f_{\text {rem }}=\exp ^{-k t}$

Decomposability was defined as decomposition rate $k$ for litters decomposing in absence of a plant. Priming was quantified by taking the natural log of decomposition rate in presence of a plant $\left(k_{P \mathrm{i}}\right)$ proportional to decomposition rate in absence of a plant $\left(k_{\text {no }}\right)$ :

Priming $_{i}=\ln \left(k_{P_{i}} / k_{n o}\right)$

Positive priming implies faster decomposition in presence of a plant, negative priming entails slower decomposition in plant presence in comparison to decomposition in absence of a plant.

Statistical analysis

All statistical analysis were performed in R, version 3.4.3 (R Core Team 2017), using the below-mentioned packages. We considered a significant level of $\alpha=0.05$ unless otherwise specified.

Coordination of trait values and decomposability among fresh shoot and root litters (hypothesis 1) was tested with standardized major axis (SMA) analysis (Warton et al. 2006), using smatr-package (Warton et al. 2012). Using the sma-function, the best line describing scatter of both $\mathrm{x}$ (values for root litters) and y (values for shoot litters) variables was estimated and tested. Residuals of the model were inspected for normality with quantile plots. Litter
$\mathrm{C}: \mathrm{N}$ and decomposability were log-transformed. Differences between crops and wild relatives (hypothesis 2) in slope, elevation, and shift of trait values along the same slope were tested for by standardised procedures (Warton et al. 2006). Correlations between litter decomposability and traits were tested as Spearman correlations, as were correlations among litter traits.

Influence of plant presence on litter decomposition was tested separately for crops and wild relatives, because crop litters decomposed in presence of crop plants, and wild litters in presence of wild plants. Linear mixed effects modelling was used to test (hypothesis 3 ) whether priming-effects differed by litter species, litter type (root vs shoot) and identity of the present plant following the protocol by Zuur et al. (2010), using the nlme-package (Pinheiro et al. 2016). Litter pool was included as random-factor. Appropriate variance structures were used to account for heteroscedasticity between strata. Optimisation of the full model ( plant ID * litter species * litter type) was done by backward-selection, to gain insight in what way experimental variable(s) significantly influenced priming. Models were compared based on maximum likelihood ratio-tests. Residuals of the final model were tested for normality and homogeneity, with Kolmogorov-Smirnov test and Levene's test. Since litters from the same litter pool were used for incubation in the three plant-presence treatments, a conservative significance level was maintained for testing hypothesis 3: only terms with $P<0.01$ were considered significant. Marginal $\mathrm{R}^{2}$ was calculated to inspect variance explained by the fixed-part of the models (Johnson 2014), using MuMIn-package (Barton 2018).

Next, the influence of litter properties (hypothesis 3) instead of litter species on priming was tested. First, litter properties (N, C, C:N, lignin and decomposability) were tested as explanatory variables in separate models, along with plant ID and litter type ( $\sim$ plant ID*litter property*litter type), according to the above protocol. Finally, full models selected by manually forward selecting significant litter properties from the single models, ranked from most to least variance explained. Final model parameters were estimated with restricted maximum likelihood (REML). Again a conservative significance level was maintained $(\alpha=0.01)$. 


\section{Results}

Root and shoot trait coordination

Chemical traits for root and shoot litter of crops and wild relatives displayed significant coordination, except for lignin concentrations (Fig. 1). Both N- and C-concentrations in root litters were positively related to concentrations in shoot litters. The standardised major axis for crop litter $\mathrm{C}$ concentrations displayed a significant shift toward the lower end of the gradient $\left(\operatorname{Wald}_{\mathrm{df}=1}=8.32, P=0.0039\right)$, compared to their wild relatives which had higher root and shoot litter C-concentrations. Crop shoot litter $\mathrm{C}: \mathrm{N}$ ratio was found to be significantly higher than that of wild relative shoot litters $\left(\right.$ Wald $_{\mathrm{df}=1}=$ 5.46, $P=0.0194)$. The estimated slope was similar for crops and wild relatives, thus the extend of coordination between root and shoot $\mathrm{C}: \mathrm{N}$ did not differ between crops and wild relatives. No significant coordination was found between root and shoot litter lignin concentrations.

Traits significantly correlated with one another (Table S1). Litter C and lignin almost always correlated positively ( $r=0.38$ to 0.76$)$. N- and $\mathrm{C}$ concentrations were not correlated in crop roots or in shoots and roots of wild relatives, but, surprisingly, they correlated positively in crop shoots $(r=0.53)$. Litter $\mathrm{C}: \mathrm{N}$ ratios were primarily determined by litter $\mathrm{N}$ concentration $(r=$ -0.99 or -1.00 ).

\section{Root and shoot litter decomposability}

Litter decomposability of crops and wild relatives was coordinated significantly between roots and shoots (Fig. 2). High shoot decomposability coincided with high root decomposability, with generally faster decomposition for shoot than root litters (above 1:1 line). Additionally, decomposability of shoot litter of crops was higher than of shoot litter of wild relatives (mean ( \pm SE) $k=0.043$ (0.002) and 0.034 (0.001) resp.), and the SMA analysis showed significant elevation of lines ( Wald df $\left.=1_{\mathrm{d}}=13.39, P=0.0003\right)$. Mean root decomposability for crops and wild relatives was comparable (mean $( \pm \mathrm{SE}) k=0.021(0.002)$ and $0.023(0.002)$ resp.). Furthermore, the coordination of root and shoot decomposability was significant for wild relatives $(P=$ $0.0015)$, but only marginally significant $(P=0.0718)$ for crops.
Correlations of root and shoot decomposability with litter traits were tested for both crops and wild relatives (Table 2). For both crops and wild relatives shoot decomposability was negatively related to litter C- and lignin-concentration. Root decomposability of crops correlated negatively with litter N-concentration, and positively with litter C:N. Root decomposability of wild relatives correlated negatively to litter C-concentration.

Influence of plant presence on litter decomposition

The influence of plant presence on litter decomposition rate, or priming effect, was tested separately for crops and wild relatives. Priming effect of crop presence on crop litter decomposition rate was influenced by the identity of the growing plant species $\left(\mathrm{F}_{2,120}=11.84\right.$, $P<0.0001)$ and by litter species $\left(\mathrm{F}_{5,120}=5.24, P=\right.$ 0.0002). Moreover, priming effects were different for crop root and shoot litters (litter species*litter type: $\mathrm{F}_{5,120}=5.15, P=0.0003$ ), but litter type (shoot or root) was not a significant main factor.

We modelled the priming effect of crops as a function of litter properties, and estimated the model parameters. Crop litter $\mathrm{N}$ was an significant factor explaining the priming effect (Table 3), while litter decomposability or lignin concentrations could not. Litter $C$ displayed a marginally significant effect $(P<0.05)$, but was regarded as non-significant given our more stringent threshold value $(\alpha=0.01)$. The relationship between priming effect and litter $\mathrm{N}$ concentrations differed for shoot and root litters (litter $\mathrm{N} *$ litter type: $F_{1,128}=7.93, P=0.0056$ ). The priming effect on shoot litters was found unrelated to litter N, but for root litters priming related positively to litter $\mathrm{N}$ $\left(\mathrm{t}_{128}=2.82, P=0.0056\right)$ (Fig. 3). Overall, priming effects from forb-presence had lower estimated priming effect than presence of own- or a grass focal plant $\left(\mathrm{t}_{128}=-3.73, P=0.0003\right)$. Moreover, priming of root litters was estimated marginally lower than shoot litter priming $\left(\mathrm{t}_{128}=-2.45, P=0.0155\right)$. In particular, decomposition of crop shoot litters were not affected by the presence of own or grass-focal plants, but forbpresence reduced decomposition rates.

For wild plants overall priming effects were negative. Priming effects differed significantly between litter species $\left(\mathrm{F}_{5,120}=9.09, P<0.0001\right)$ and differed marginally between the different species of growing plants at a conservative significance level $\left(\mathrm{F}_{2,120}=\right.$ 
(a) Nitrogen

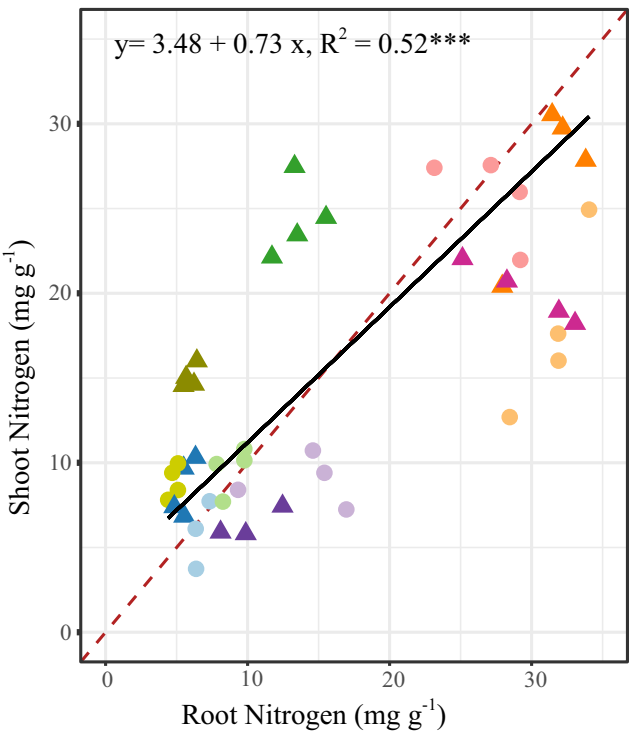

(c) $\mathrm{CN}$

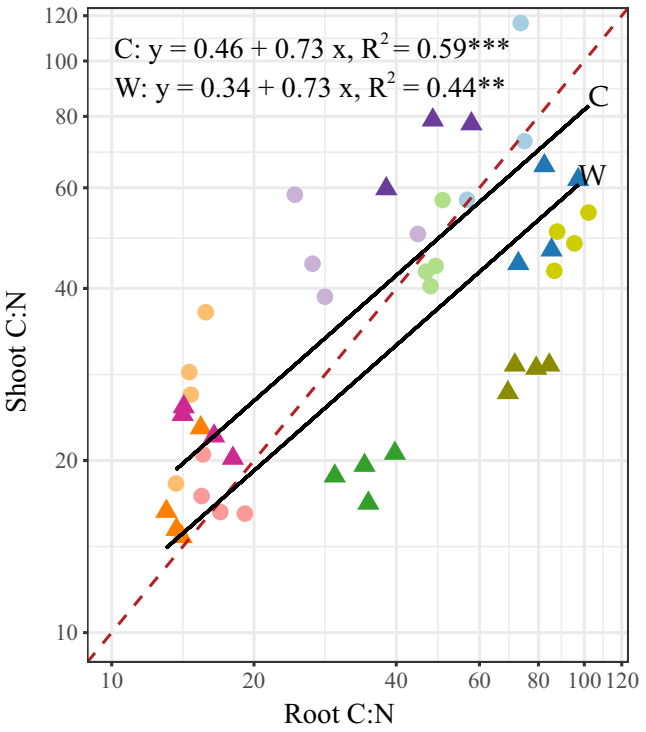

Fig. 1 Standardize major axis (SMA) regression between root and shoot litter traits nitrogen (a) and carbon concentration (b), C:N ratio (c), lignin concentration (d), for crop plants and wild relatives. SMA for crops in $\mathrm{b}$ shifted significantly to lower end $(P=$

4.53, $P=0.0126, \alpha=0.01)$. Strongest plant-presence induced reduction of decomposition occured with A. elatius litters, while priming effects were neutral for $R$. raphanistrum to positive for Festuca rubra. No overall differences of litter type were observed, nor was the interaction between litter species and litter type significant. (b) Carbon

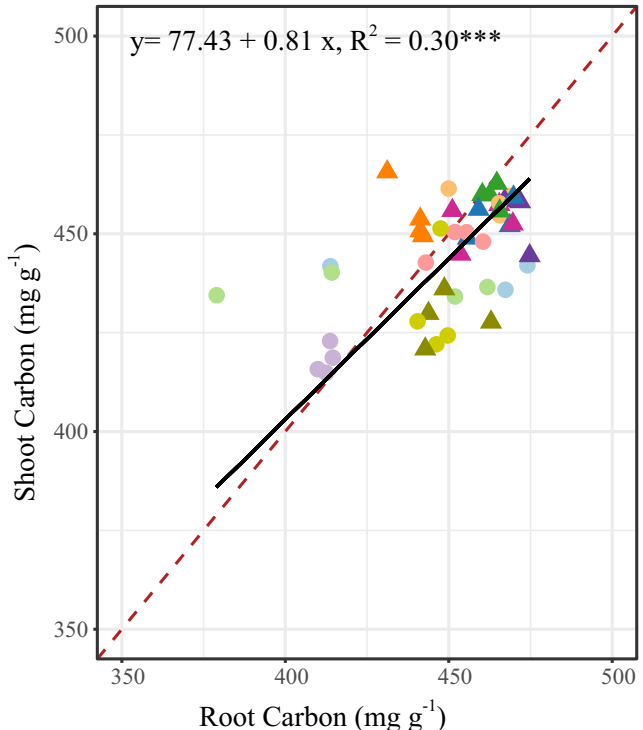

(d) Lignin

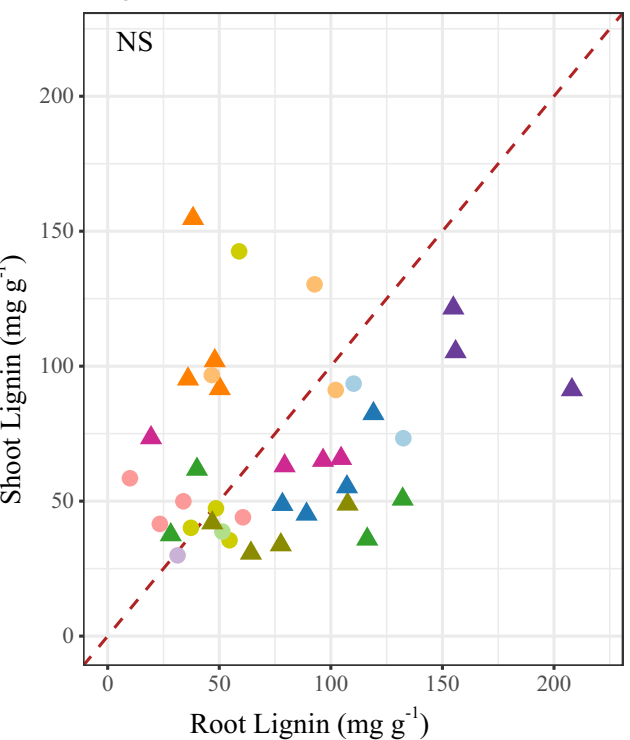

Litter species

A. sativa

- A. elatius

L. perenne

- F.rubra

T. repens

- T. pratense

V. sativa

- V. cracca

R. sativus

- R. raphanistrum

- C. endivia

C. intybus

Domes ticated

- Crop (C)

$\Delta$ Wild (W)
$0.0194)$. SMA for crops in c significantly higher than wild plants $(P=0.0194)$. Dashed red line indicates 1:1 line for reference. Note, axes in c are on log-scale. For full names of plant species see Table 1. *** $P<0.001$, ** $P<0.01, * P<0.05$
Upon modelling priming effect on wild plant litters as a function of litter properties rather than litter species, present plant identity did differentially effect priming (Table 3), with stronger negative priming effects in presence of a forb $\left(t_{119}=-2.35, P=0.0207\right.$, Fig. 4). The optimal regression model explaining priming effects of wild plants included litter decomposability as a 


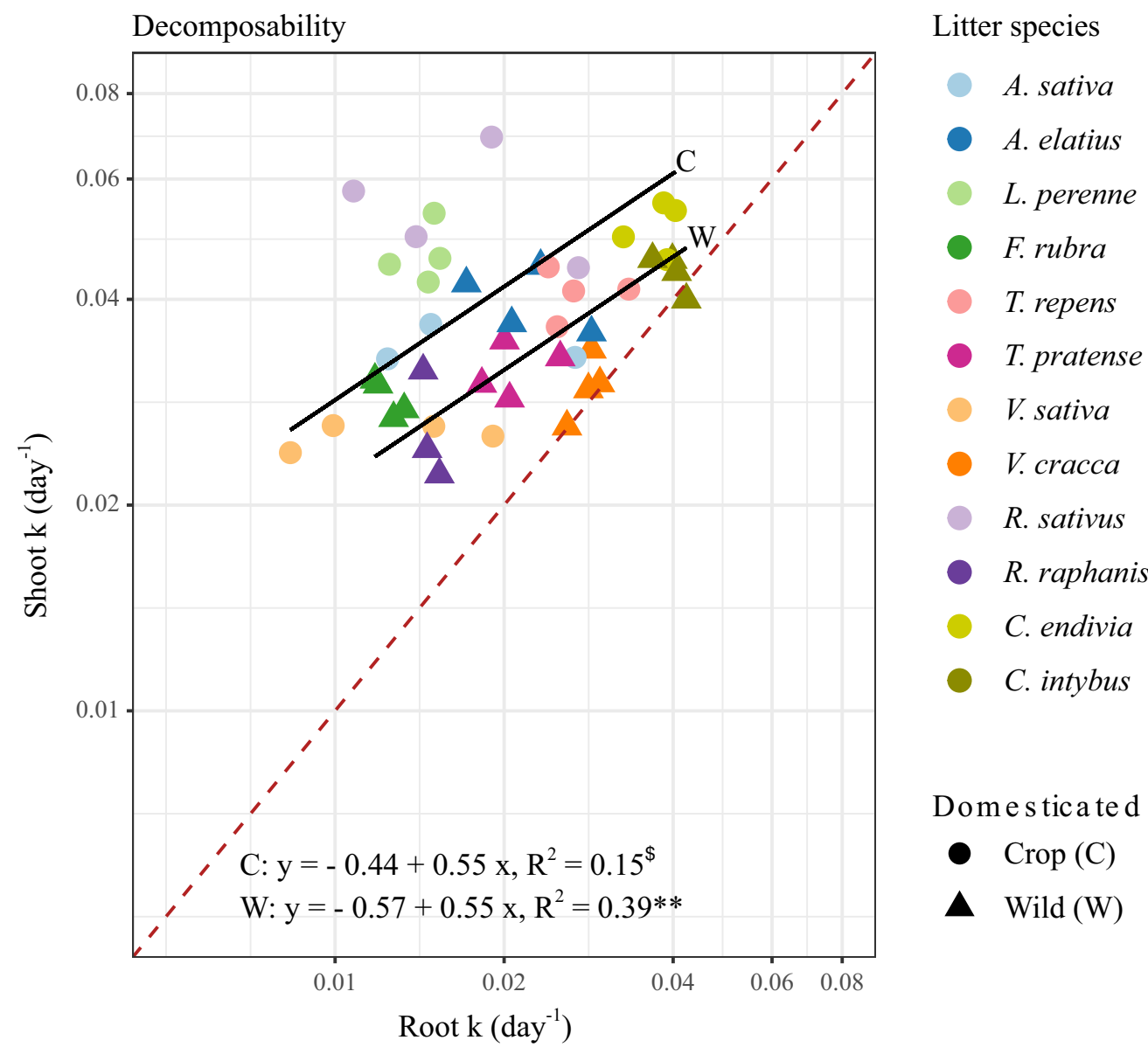

Fig. 2 Standardize major axis (SMA) regression between root and shoot litter decomposability, for crop plants and wild relatives. Crop SMA displayed significant higher than wild plant SMA $(P=0.0003)$.

Table 2 Spearman correlation coefficients $(r)$ for crops and wild relatives, between shoot and root decomposability and their respective litter traits

\begin{tabular}{llll}
\hline Litter traits & & Shoot $k\left(\right.$ day $\left.^{-1}\right)$ & Root $k\left(\right.$ day $\left.^{-1}\right)$ \\
\hline Crops & $\mathrm{N}$ & -0.27 & $-0.43^{*}$ \\
& $\mathrm{C}$ & $-0.71^{* * *}$ & -0.06 \\
& $\mathrm{C}: \mathrm{N}$ & 0.25 & $0.42^{*}$ \\
\multirow{4}{*}{ Wild relatives } & Lignin & $-0.60^{* *}$ & -0.33 \\
& $\mathrm{~N}$ & -0.27 & -0.15 \\
& $\mathrm{C}$ & $-0.73^{* * *}$ & $-0.65^{* *}$ \\
& $\mathrm{C}: \mathrm{N}$ & 0.26 & 0.11 \\
& Lignin & $-0.56^{* *}$ & -0.31 \\
\hline
\end{tabular}

*** $P<0.001, * * P<0.01, * P<0.05$
Dashed red line indicates 1:1 line. Note, axes are on log-scale. See Table 1 for full species names. $* * P<0.01,{ }^{\$} P<0.1$

significant factor (Table 3 ). Litter lignin was only marginally significant $(P<0.05$, at $\alpha=0.01)$, and litter $\mathrm{C}$ nor litter $\mathrm{N}$ contributed significantly to the model. Litter decomposability negatively influenced priming $\left(\mathrm{t}_{119}=\right.$ $-7.32, P<0.0001$ ), with the litters of highest decomposability experiencing the strongest reduction of decomposition rates by the present plant. Decomposition rate of root litters was reduced more by plant presence than shoot decomposition $\left(\mathrm{t}_{119}=-3.62, P=0.004\right)$ (Fig. 4).

\section{Discussion}

Plant roots contribute profoundly to $\mathrm{C}$ and $\mathrm{N}$ cycling (Freschet et al. 2013), particularly in arable systems (Jackson et al. 2017). We found that crop shoots on 
Table 3 Results of the regression analysis modelling priming effects by species of present plant (plant ID), litter properties (litter N, litter lignin, decomposability) and litter type (root or shoot)

\begin{tabular}{|c|c|c|c|c|c|c|c|}
\hline & \multicolumn{3}{|c|}{ Crops $\left(\mathrm{R}_{\text {marginal }}^{2}=0.094\right)$} & & \multicolumn{3}{|c|}{ Wild relatives $\left(\mathrm{R}_{\text {marginal }}^{2}=0.301\right)$} \\
\hline & Df & $\mathrm{F}$ & $P$ & & Df & $\mathrm{F}$ & $P$ \\
\hline Plant ID & 2128 & 11.20 & $<0.0001$ & Plant ID & 2,119 & 7.45 & 0.0009 \\
\hline Litter N & 1128 & 8.82 & 0.0036 & Decomposability & 1,119 & 35.39 & $<0.0001$ \\
\hline Litter type & 1128 & 0.01 & 0.9388 & Litter lignin & 1,119 & 5.90 & 0.0167 \\
\hline Litter N*type & 1128 & 7.93 & 0.0056 & Litter type & 1,119 & 13.09 & 0.0004 \\
\hline
\end{tabular}

Bold values indicate significant terms $(\alpha=0.01)$

(a) Crop shoots

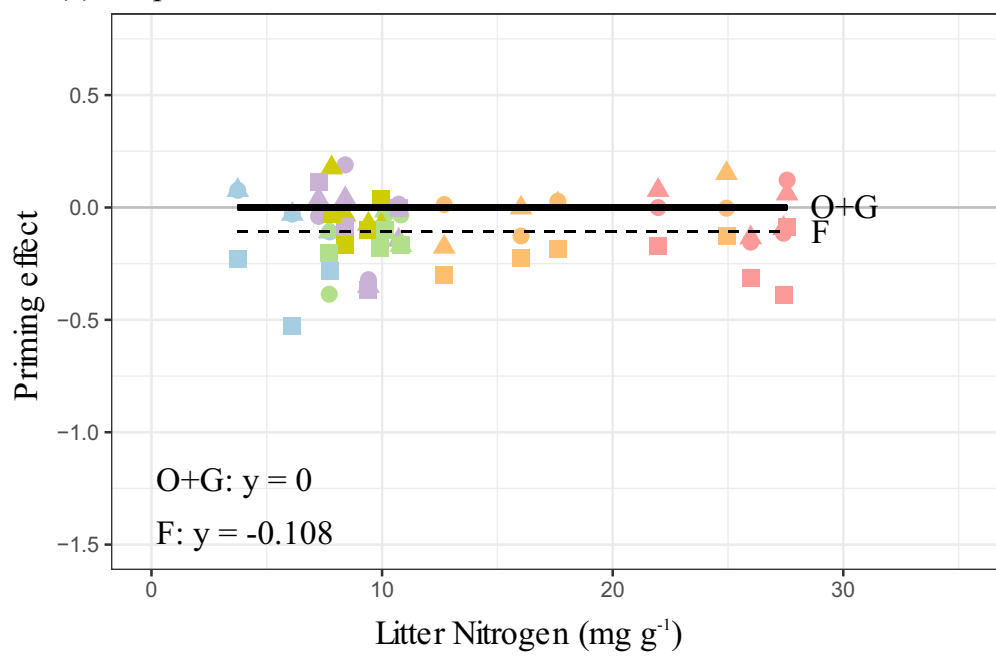

(b) Crop roots

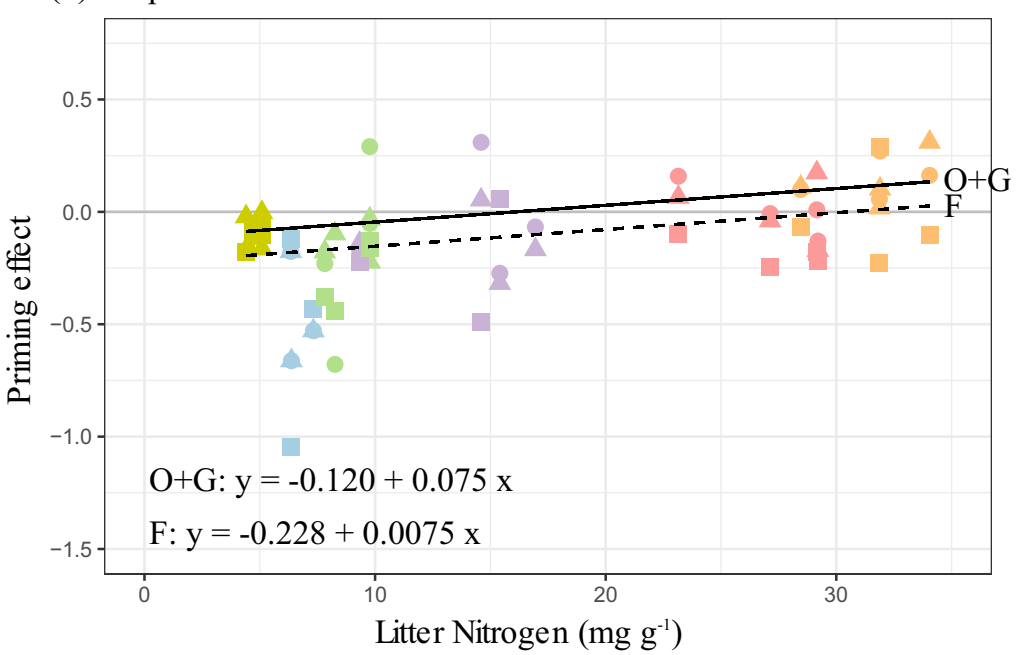

Litter species
A. sativa
L. perenne
T. repens
V. sativa
R. sativus
C. endivia

\section{Present plant ID}

- Omn (O)

- Grass (G) - A. sativa

- Forb (F) - C. endivia

absence. Regression lines are based on multiple-linear regression

Fig. 3 Priming effect of presence of own-, grass- or forb-plants on shoot (a) or root (b) litters of crops in relation to litter N-concentration. Priming was calculated as the natural log of decomposition rate in plant presence proportional to decomposition rate in plant analysis (see Table 3) and subsequent parameter estimation by restricted maximum likelihood. See Table 1 for full species names 


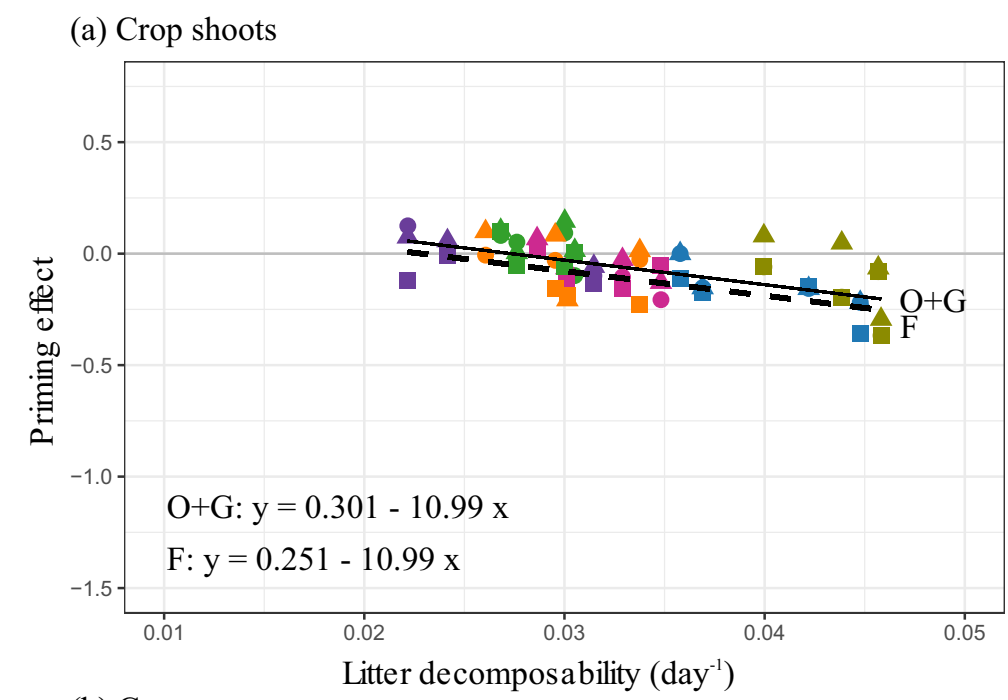

Litter species

- A. elatius

- F. rubra

- T.pratense

- V. cracca

- $R$. raphanistrum

- C. intybus

Present plant ID

- Own (O)

- Grass (G) - A. elatius

- Forb (F) - C. intybus

(b) Crop roots

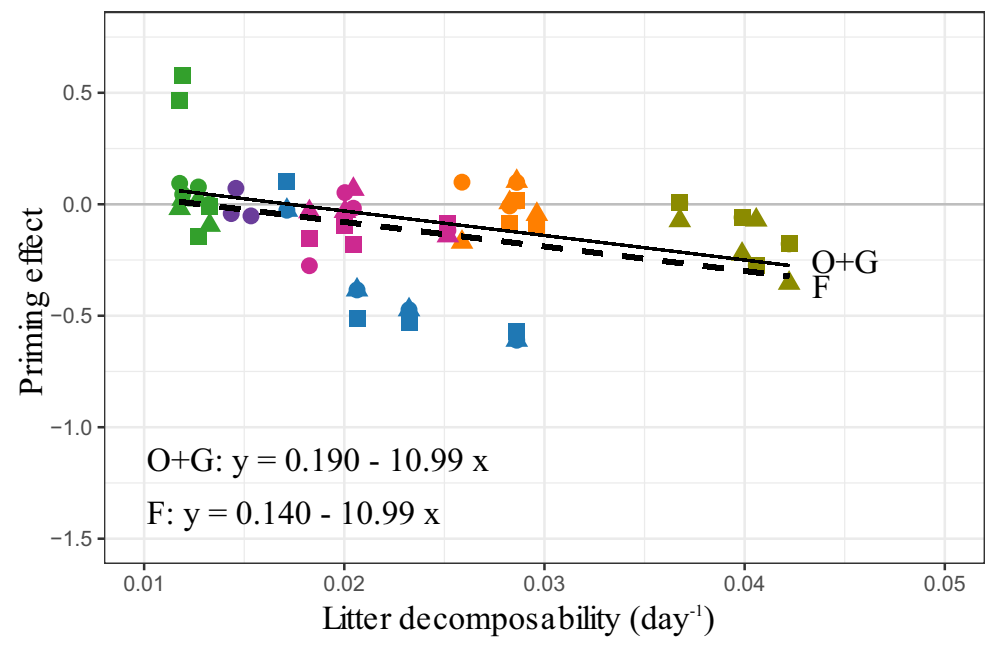

Fig. 4 Priming effect of presence of own-, grass- or forb-plants on shoot (a) or root (b) litters of wild plants in relation to litter decomposability. Priming was calculated as the natural log of decomposition rate in plant presence proportional to

average decomposed 1.98 faster than crop roots, while for closely related wild plants shoots decomposed 1.43 times faster than roots. Not only do our results confirm that $\mathrm{C}$ - cycling from belowground litter is slower than from aboveground litter (Freschet et al. 2013), they also demonstrate that fresh organic matter dynamics differ between agriculture and natural grasslands. We discuss the suitability of shoot decomposability and litter traits as a proxy for root decomposability and litter traits. Additionally, we found that growing plants reduce litter decomposition rates and discuss the possible underlying mechanisms of rhizosphere priming in relation to litter quality. decomposition rate in plant absence. Regression lines are based on multiple-linear regression analysis (see Table 3) and subsequent parameter estimation by restricted maximum likelihood. See Table 1 for full species names

Coordination of root and shoot litter decomposability and traits

Root and shoot litter decomposability was expected to be ranked similarly as a consequence of coordinated carbon and nutrient economics in above- and belowground plant parts (Freschet et al. 2013; Reich 2014). In line with our first hypothesis, decomposability of root litters was slower but coordinated to shoot litter decomposability. Moreover, litter N-, C- concentration and $\mathrm{C}: \mathrm{N}$ ratio were coordinated between shoot and root litters. Freschet et al. (2010) found that traits related to structural investment, such as $\mathrm{C}$ - and lignin 
concentration, are stronger correlated across plant organs than nutritional-traits such as N-concentration. However, our shoot and root litter lignin-concentration did not display coordination. The function of fine roots could explain the lack of coordination of lignin-concentrations. Fine roots (diameter $<2 \mathrm{~mm}$ ) can included several root orders, of which most have an absorptive function (orders 1-3) and some a transport function (order $4<$ ) (McCormack et al. 2015). The ratio of absorptive and transport roots within the fine-root fraction vary between herbaceous and annual crop plants, as well as between forbs and grasses (McCormack et al. 2015), which could be a biological source of variation of the lignin-concentrations found among our root litters. Additionally, the absence of coordination in leaf and root lignin concentrations could be related to differences in carbon economics among above- and belowground plant organs which is currently an ongoing discussion (Kramer-Walter et al. 2016; Roumet et al. 2016; Weemstra et al. 2016). As root and shoot growth have different constraints and functions, the same traits in shoots and roots could have a different role in, respectively, above- and belowground carbon economics (Kramer-Walter et al. 2016; Weemstra et al. 2016).

\section{Domestication effects on litter traits}

and decomposability

We expected that crop litters would decompose faster than litters of wild relatives as a consequence of more acquisitive trait values. Shoot litters of crops were found to decompose faster than shoot litters of wild relatives at similar root decomposition rates. Our results are in agreement with García-Palacios et al. (2013), who demonstrated faster decomposition of crop leaf litters in comparison to wild ancestors due to litter lignin concentrations which were lower in crops than in wild relatives.

Our crops and wild relatives displayed differences in trait values. In line with hypothesis two, crop litters showed lower $\mathrm{C}$ concentrations for both root and shoot litters compared to their wild relatives. Surprisingly, crops had higher $\mathrm{C}: \mathrm{N}$ ratios in shoot litter than the wild plants. This pattern was driven by two wild plant species, F. rubra and C. intybus, with high Nconcentrations and low $\mathrm{C}: \mathrm{N}$ ratios in their shoot litters. The observed root $\mathrm{C}: \mathrm{N}$ ratio for both species agree with values found in earlier studies (Orwin et al. 2010; Saar et al. 2016), as is shoot C:N ratio for C. intybus (GarcíaPalacios et al. 2013), and F. rubra (Orwin et al. 2010). A more extensive comparison of crop and related plant species comparison is needed to test if the difference in shoot $\mathrm{C}: \mathrm{N}$ ratio between crop and wild plants is a general pattern or a consequence of selecting two wild plant species with deviating trait values. Moreover, domestication is a multifaceted phenomenon (Mariotte et al. 2018; Milla et al. 2015). Our crop species (a grain, a vegetable and cover crops) were domesticated for different purposes and different length of time. Here, we focussed on domestication effects caused by general differences in selection pressures between agricultural and natural ecosystems, such as management intensity and resource availability, rather than consequences of specific selection pressures for specific crop usage (Meyer et al. 2012).

We tested whether litter decomposability could be explained by litter trait values. In line with our expectations, we found that shoot decomposability was negatively correlated with litter C-and lignin concentrations for litter of both crops and wild relatives. Moreover, root decomposability of wild plants was negatively correlated with litter C-concentrations. However, for crop root decomposability litter $\mathrm{N}$ correlated significantly, and surprisingly, negatively. This correlation appears to be driven by the high root decomposability of $C$. endivia which had lowest root $\mathrm{N}$ concentrations, and relatively low root decomposability of $V$. sativa despite its high $\mathrm{N}$ concentrations. Root $\mathrm{N}$ concentration has been found a poor predictor of root decomposition in other studies, which could be related to root branching order and cooccurring low quality of carbon compounds (phenols, tannins, non-structural carbohydrates) (Beidler and Pritchard 2017; Sun et al. 2018). Increased decomposition rates of shoot litters of crops and wild ancestors were found to coincide with increased mineral $\mathrm{N}$ availability (García-Palacios et al. 2013), which puts forward the question whether this relationship is also present for root litters. Shoot decomposability could act as a proxy for root decomposability for wild plants but not for crops, as the controlling mechanisms seem different for decomposition of crop root and shoot litter.

It should be noted that our measurements were performed on fresh, non-senesced litter. Plants resorb resources from shoots or roots to different degrees (Aerts 1990), and trait values for naturally senesced litter are likely to deviate from our results. Also, roots senesce more gradually that shoots (Hobbie et al. 2010). Thus our result represent the degree of trait coordination in live shoot and roots, and related decomposability is 
especially relevant for managed systems in which nonsenesced plant parts are incorporated into the soil. Also, intraspecific trait-values can vary depending on the population of wild plant or crop cultivar. However, for the traits we focussed on the interspecific variation is known to be larger than the intraspecific variation when the plants are grown under a fixed environmental condition (Pérez-Harguindeguy et al. 2013).

Influence of a growing plant on litter decomposition

The presence of a growing plant root in our study had predominantly negative effects on litter decomposition. Most litterbags contained in-grown roots from the present plant (these were removed to accurately measure the fraction of litter remaining after incubation), hence plant-litter interactions had occurred. Litter decomposition rates can be slowed down by low soil moisture levels as a consequence of evapotranspiration (Shi et al. 2018). However, we minimised water-stress as a possible cause of negative priming by daily watering. Literature reports two other potential mechanisms by which plant presence can reduce decomposition, namely preferential substrate utilisation and competition for $\mathrm{N}$ between plant and the saprotrophic community (Chen et al. 2014; Dijkstra et al. 2013). The occurrence of these mechanisms depends on the available mineral N (Chen et al. 2014; Dijkstra et al. 2013). For example, Saar et al. (2016) found that the presence of Trifolium repens reduced the decomposition of non-legume root litters. As legumes are self-sufficient in their $\mathrm{N}$-supply through the mutualism with $\mathrm{N}$-fixing Rhizobia, it was unlikely that T. repens competed for $\mathrm{N}$ with the microbial decomposers. Instead, negative priming was proposed to be the effect of preferential substrate utilisation by the saprotrophic soil microbes (Saar et al. 2016). In the current experiment, reduction of decomposition was observed in presence of forbs and grasses, which makes preferential substrate utilisation an unlikely explanation. Instead the observed negative priming could result from mineral $\mathrm{N}$ competition between the present plant and the saprotrophic microbes.

The relationships found between priming effects and litter quality parameters suggests that the saprotrophic microbes experienced $\mathrm{N}$ competition with the plant in varying extent. Priming effects on shoot and root litters of wild plants related negatively with increasing litter decomposability. For crop root litters, we found a positive relationship between priming and root litter $\mathrm{N}$ - concentration. Additionally, decomposability of crop roots was lower than of crop shoots, and was negatively correlated with root litter N (Table 2). It has been suggested that the direction and magnitude of priming effects can be explained by the life-history traits of the decomposer microorganisms dominating the decomposing litter (Dijkstra et al. 2013; Fontaine et al. 2003). Rhizodeposits from present plant roots hypothetically facilitate slowgrowing microbial K-strategists decomposing recalcitrant substrates, while decomposition governed by fastgrowing r-strategist could be reduced because of competition for $\mathrm{N}$ with the growing plant (Blagodatskaya et al. 2007; Fontaine et al. 2003). A functional characterisation of the saprotrophic community in presence and absence of a growing plant along a gradient of litter qualities would enable testing of this hypothesis. Labelling studies with $\mathrm{N}$ and $\mathrm{C}$ isotopes are required to test litter $\mathrm{N}$ concentrations as a controlling factor of priming, and establish if the observed reduction of decomposition rates are paralleled with reduced C-mineralisation from litter.

Across all litter species, we found the priming effect to depend on the identity of the present plant, which is in line with our expectation. Priming effects have been reported to differ between grass species during litter decomposition (Van der Krift et al. 2001; van der Krift et al. 2002). Shi et al. (2018) demonstrated that plant presence can alter the potential capacity of substrate utilisation, as microbial gene abundance coding for degradation of low molecular weight compounds increased and macromolecule degrading gene abundance decreased. Plant speciesspecific differences in rhizodeposition quantity and quality and their influence on the functional capacity of the saprotrophic community have been proposed as an underlying mechanism, as are differences in plant photosynthetic activity and in N-uptake from soil (Huo et al. 2017; Kuzyakov and Cheng 2001).

\section{Conclusion}

C-cycling estimates that are solely based on decomposition studies of aboveground plant parts will overestimate plant biomass turn-over, because root litters decomposed slower than shoot litters. Decomposition of shoot and root litter depended on its structural (carbon) and nutritional (nitrogen) quality. While shoots of wild plants can serve as a proxy for root decomposition of wild plants, this is not the case for crop shoots. Root decomposition of agricultural crops seems to be controlled differently 
than crop shoots. Moreover, presence of a growing plant can reduce litter decomposition rates, with most negative effects for easily decomposable litters as a potential consequence of competition for $\mathrm{N}$ between plant and saprotrophic microbes, and different responses of microbial r- and K-strategists. These results can have important implications for $\mathrm{C}$ and $\mathrm{N}$ cycling from crop residues in agriculture as plant induced reduction in litter decomposition could affect synchronisation of $\mathrm{N}$ mineralisation and $\mathrm{N}$ demand of the crop.

Acknowledgements We thank Elly Nijenhuis, Hashmattulah Hotak and Henk Martens for practical support, Richard van Logtestijn and Rob Broekman for lignin-measurements. We also thank Liesje Mommer for reviewing our manuscript, and two anonymous reviewers for their constructive comments. This work was financially supported by NWO-ALW VIDI to GBDD (grant no. 864.11003).

\section{Compliance with ethical standards}

Conflict of interest The authors declare no conflict of interest.

Data availability The data collected and analysed in this study are available in the DANS EASY repository (https://doi. org/10.17026/dans-zqm-uydw).

Open Access This article is distributed under the terms of the Creative Commons Attribution 4.0 International License (http:// creativecommons.org/licenses/by/4.0/), which permits unrestricted use, distribution, and reproduction in any medium, provided you give appropriate credit to the original author(s) and the source, provide a link to the Creative Commons license, and indicate if changes were made.

Publisher's note Springer Nature remains neutral with regard to jurisdictional claims in published maps and institutional affiliations.

\section{References}

Aerts R (1990) Nutrient use efficiency in evergreen and deciduous species from heathlands. Oecologia 84:391-397. https://doi. org/10.1007/bf00329765

Barel JM, Kuyper TW, de Boer W, Douma JC, De Deyn GB (2018) Legacy effects of diversity in space and time driven by winter cover crop biomass and nitrogen concentration. J Appl Ecol 55:299-310. https://doi.org/10.1111/1365-2664.12929

Barton K (2018) MuMIn: Multi-Model Inference. R package version 1(42):1 https://CRAN.R-project.org/package= MuMIn
Beidler KV, Pritchard SG (2017) Maintaining connectivity: understanding the role of root order and mycelial networks in fine root decomposition of woody plants. Plant Soil 420:19-36. https://doi.org/10.1007/s11104-017-3393-8

Bek S (1994) Mineralization of 14C-labelled unripe straw in soil with and without rape (Brassica napus L.). Biol Fertil Soils 17:21-26. https://doi.org/10.1007/bf00418667

Bingeman CW, Varner JE, Martin WP (1953) The effect of the addition of organic materials on the decomposition of an organic soil. Soil Science Society Proceedings 17:4. https://doi.org/10.2136/sssaj1953.03615995001700010008x

Birouste M, Kazakou E, Blanchard A, Roumet C (2012) Plant traits and decomposition: are the relationships for roots comparable to those for leaves? oAnnals of Botany 109:463-472

Blagodatskaya EV, Blagodatsky SA, Anderson TH, Kuzyakov Y (2007) Priming effects in Chernozem induced by glucose and $\mathrm{N}$ in relation to microbial growth strategies. Appl Soil Ecol 37:95-105. https://doi.org/10.1016/j.apsoil.2007.05.002

Chen R, Senbayram M, Blagodatsky S, Myachina O, Dittert K, Lin X, Blagodatskaya E, Kuzyakov Y (2014) Soil C and N availability determine the priming effect: microbial $\mathrm{N}$ mining and stoichiometric decomposition theories. Glob Chang Biol 20:2356-2367. https://doi.org/10.1111/gcb.12475

Cheng W, Coleman DC (1990) Effect of living roots on soil organic matter decomposition. Soil Biol Biochem 22:781787

Cornwell WK, Cornelissen JHC, Amatangelo K, Dorrepaal E, Eviner VT, Godoy O, Hobbie SE, Hoorens B, Kurokawa H, Pérez-Harguindeguy N, Quested HM, Santiago LS, Wardle DA, Wright IJ, Aerts R, Allison SD, Van Bodegom P, Brovkin V, Chatain A, Callaghan TV, Díaz S, Garnier E, Gurvich DE, Kazakou E, Klein JA, Read J, Reich PB, Soudzilovskaia NA, Vaieretti MV, Westoby M (2008) Plant species traits are the predominant control on litter decomposition rates within biomes worldwide. Ecol Lett 11:10651071. https://doi.org/10.1111/j.1461-0248.2008.01219.x

Dias T, Dukes A, Antunes PM (2014) Accounting for soil biotic effects on soil health and crop productivity in the design of crop rotations. J Sci Food Agric 95:447-454. https://doi. org/10.1002/jsfa.6565

Dijkstra F, Carrillo Y, Pendall E, Morgan J (2013) Rhizosphere priming: a nutrient perspective. Front Microbiol 4. https://doi.org/10.3389/fmicb.2013.00216

Fontaine S, Mariotti A, Abbadie L (2003) The priming effect of organic matter: a question of microbial competition? Soil Biol Biochem 35:837-843. https://doi.org/10.1016/S00380717(03)00123-8

Freschet GT, Cornelissen JHC, van Logtestijn RSP, Aerts R (2010) Evidence of the 'plant economics spectrum' in a subarctic flora. J Ecol 98:362-373. https://doi.org/10.1111/j.13652745.2009.01615.x

Freschet GT, Aerts R, Cornelissen JHC (2012) A plant economics spectrum of litter decomposability. Funct Ecol 26:56-65. https://doi.org/10.1111/j.1365-2435.2011.01913.x

Freschet GT, Cornwell WK, Wardle DA, Elumeeva TG, Liu W, Jackson BG, Onipchenko VG, Soudzilovskaia NA, Tao J, Cornelissen JHC (2013) Linking litter decomposition of above- and below-ground organs to plant-soil feedbacks worldwide. J Ecol 101:943-952. https://doi.org/10.1111 /1365-2745.12092 
García-Palacios P, Milla R, Delgado-Baquerizo M, Martín-Robles N, Álvaro-Sánchez M, Wall DH (2013) Side-effects of plant domestication: ecosystem impacts of changes in litter quality. New Phytol 198:504-513. https://doi.org/10.1111 /nph. 12127

Hobbie SE, Oleksyn J, Eissenstat DM, Reich PB (2010) Fine root decomposition rates do not mirror those of leaf litter among temperate tree species. Oecologia 162:505-513. https://doi. org/10.1007/s00442-009-1479-6

Huo C, Luo Y, Cheng W (2017) Rhizosphere priming effect: a meta-analysis. Soil Biol Biochem 111:78-84. https://doi. org/10.1016/j.soilbio.2017.04.003

Jackson RB, Lajtha K, Crow SE, Hugelius G, Kramer MG, Piñeiro G (2017) The ecology of soil carbon: pools, vulnerabilities, and biotic and abiotic controls. Annu Rev Ecol Evol Syst 48: 419-445. https://doi.org/10.1146/annurev-ecolsys-112414054234

Johnson PCD (2014) Extension of Nakagawa \& Schielzeth's R2GLMM to random slopes models. Methods Ecol Evol 5: 944-946. https://doi.org/10.1111/2041-210x.12225

Kramer-Walter KR, Bellingham PJ, Millar TR, Smissen RD, Richardson SJ, Laughlin DC (2016) Root traits are multidimensional: specific root length is independent from root tissue density and the plant economic spectrum. J Ecol 104: 1299-1310. https://doi.org/10.1111/1365-2745.12562

Kuzyakov Y (2010) Priming effects: interactions between living and dead organic matter. Soil Biol Biochem 42:1363-1371. https://doi.org/10.1016/j.soilbio.2010.04.003

Kuzyakov Y, Cheng W (2001) Photosynthesis controls of rhizosphere respiration and organic matter decomposition. Soil Biol Biochem 33:1915-1925. https://doi.org/10.1016 /S0038-0717(01)00117-1

Mariotte P, Mehrabi Z, Bezemer TM, De Deyn GB, Kulmatiski A, Drigo B, Veen GF, van der Heijden MGA, Kardol P (2018) Plant-soil feedback: bridging natural and agricultural sciences. Trends Ecol Evol 33:129-142. https://doi. org/10.1016/j.tree.2017.11.005

McCormack ML, Dickie IA, Eissenstat DM, Fahey TJ, Fernandez CW, Guo D, Helmisaari HS, Hobbie EA, Iversen CM, Jackson RB, Leppälammi-Kujansuu J, Norby RJ, Phillips RP, Pregitzer KS, Pritchard SG, Rewald B, Zadworny M (2015) Redefining fine roots improves understanding of below-ground contributions to terrestrial biosphere processes. New Phytol 207:505-518. https://doi.org/10.1111 /nph.13363

Meyer RS, DuVal AE, Jensen HR (2012) Patterns and processes in crop domestication: an historical review and quantitative analysis of 203 global food crops. New Phytol 196:29-48. https://doi.org/10.1111/j.1469-8137.2012.04253.x

Milla R, Morente-López J, Alonso-Rodrigo JM, Martín-Robles N, Stuart Chapin F (2014) Shifts and disruptions in resource-use trait syndromes during the evolution of herbaceous crops. Proc R Soc B Biol Sci 281:20141429. https://doi. org/10.1098/rspb.2014.1429

Milla R, Osborne CP, Turcotte MM, Violle C (2015) Plant domestication through an ecological lens. Trends Ecol Evol 30: 463-469. https://doi.org/10.1016/j.tree.2015.06.006

Olson JS (1963) Energy storage and the balance of producers and decomposers in ecological systems. Ecology 44:322-331. https://doi.org/10.2307/1932179
Orwin KH, Buckland SM, Johnson D, Turner BL, Smart S, Oakley S, Bardgett RD (2010) Linkages of plant traits to soil properties and the functioning of temperate grassland. J Ecol 98:1074-1083. https://doi.org/10.1111/j.13652745.2010.01679.x

Pérez-Harguindeguy N, Díaz S, Garnier E, Lavorel S, Poorter H, Jaureguiberry P, Bret-Harte MS, Cornwell WK, Craine JM, Gurvich DE, Urcelay C, Veneklaas EJ, Reich PB, Poorter L, Wright IJ, Ray P, Enrico L, Pausas JG, De Vos AC, Buchmann N, Funes G, Quétier F, Hodgson JG, Thompson K, Morgan HD, Ter Steege H, Van Der Heijden MGA, Sack L, Blonder B, Poschlod P, Vaieretti MV, Conti G, Staver AC, Aquino S, Cornelissen JHC (2013) New handbook for standardised measurement of plant functional traits worldwide. Aust J Bot 61:167-234. https://doi.org/10.1071 /bt12225

Pinheiro J, Bates D, DebRoy S, Sarkar D, Core Team R (2016) Nlme: linear and nonlinear mixed effects models. R package version 3:1-137 http:/CRAN.R-project.org/package=nlme

Poorter H, Villar R (1997) The fate of acquired carbon in plants: chemical composition and construction cost. In: Bazzaz FA, Grace J (eds) Plant resource allocation. Academic Press, San Diego

R Core Team (2017) R: A language and environment for statistical computing. R version 3.4.1 edn. R Foundation for Statistical Computing, Vienna, Austria, http://www.R-project.org

Reich PB (2014) The world-wide 'fast-slow' plant economics spectrum: a traits manifesto. J Ecol 102:275-301. https://doi.org/10.1111/1365-2745.12211

Roucou A, Violle C, Fort F, Roumet P, Ecarnot M, Vile D, Martin A (2018) Shifts in plant functional strategies over the course of wheat domestication. J Appl Ecol 55:25-37. https://doi. org/10.1111/1365-2664.13029

Roumet C, Birouste M, Picon-Cochard C, Ghestem M, Osman N, Vrignon-Brenas S, Kf C, Stokes A (2016) Root structurefunction relationships in 74 species: evidence of a root economics spectrum related to carbon economy. New Phytol 210:815-826. https://doi.org/10.1111/nph.13828

Saar S, Semchenko M, Barel JM, De Deyn GB (2016) Legume presence reduces the decomposition rate of non-legume roots. Soil Biol Biochem 94:88-93. https://doi.org/10.1016 /j.soilbio.2015.11.026

Shi S, Herman DJ, He Z, Pett-Ridge J, Wu L, Zhou J, Firestone MK (2018) Plant roots alter microbial functional genes supporting root litter decomposition. Soil Biol Biochem 127:90-99. https://doi.org/10.1016/j.soilbio.2018.09.013

Silver WL, Miya RK (2001) Global patterns in root decomposition: comparisons of climate and litter quality effects. Oecologia 129:407-419. https://doi.org/10.1007 /s004420100740

Sun T, Hobbie SE, Berg B, Zhang H, Wang Q, Wang Z, Hättenschwiler S (2018) Contrasting dynamics and trait controls in first-order root compared with leaf litter decomposition. Proc Natl Acad Sci 115:10392-10397. https://doi. org/10.1073/pnas.1716595115

Swift MJ, Heal OW, Anderson J (1978) Decomposition in terrestrial ecosystems. Blackwell Scientific, Oxford

Thorup-Kristensen K, Magid J, Jensen LS (2003) Catch crops and green manures as biological tools in nitrogen management in temperate zones. Adv Agron 79:227-302. https://doi. org/10.1016/s0065-2113(02)79005-6 
Van der Krift TAJ, Gioacchini P, Kuikman PJ, Berendse F (2001) Effects of high and low fertility plant species on dead root decomposition and nitrogen mineralisation. Soil Biol Biochem 33:2115-2124. https://doi.org/10.1016/s00380717(01)00145-6

van der Krift TAJ, Kuikman PJ, Berendse F (2002) The effect of living plants on root decomposition of four grass species. Oikos 96:36-45. https://doi.org/10.1034/j.16000706.2002.10978.x

Vivanco L, Austin AT (2006) Intrinsic effects of species on leaf litter and root decomposition: a comparison of temperate grasses from north and South America. Oecologia 150:97107. https://doi.org/10.1007/s00442-006-0495-z

Wagger MG, Cabrera ML, Ranells NN (1998) Nitrogen and carbon cycling in relation to cover crop residue quality. $\mathrm{J}$ Soil Water Conserv 53:214-218

Warton DI, Wright IJ, Falster DS, Westoby M (2006) Bivariate line-fitting methods for allometry. Biol Rev 81:259-291. https://doi.org/10.1017/S1464793106007007
Warton DI, Duursma RA, Falster DS, Taskinen S (2012) Smatr 3an $\mathrm{R}$ package for estimation and inference about allometric lines. Methods Ecol Evol 3:257-259. https://doi.org/10.1111 j.2041-210X.2011.00153.x

Weemstra M, Mommer L, Visser EJW, van Ruijven J, Kuyper TW, Mohren GMJ, Sterck FJ (2016) Towards a multidimensional root trait framework: a tree root review. New Phytol 211: 1159-1169. doi: doi:https://doi.org/10.1111/nph.14003

Zhang D, Hui D, Luo Y, Zhou G (2008) Rates of litter decomposition in terrestrial ecosystems: global patterns and controlling factors. J Plant Ecol 1:85-93. https://doi.org/10.1093 /jpe/rtn002

Zuur AF, Ieno EN, Elphick CS (2010) A protocol for data exploration to avoid common statistical problems. Methods Ecol Evol 1:3-14. https://doi.org/10.1111/j.2041-210 X.2009.00001.x 